Received: October 29, 2017

Revision received: March 7, 2018

\title{
Study on Practical Education Mode of Local Applied Undergraduate Colleges and Universities*
}

\author{
Min Wang ${ }^{1}$ \\ Qilu Normal University
}

\begin{abstract}
The cultivation of applied talents in local colleges and universities is the main channel to convey talents for social production, application and practice. Therefore, the cultivation of practical education of applied talents is more important. Based on the importance of applied teaching mode, this study analyzes the main problems and reasons in the practical teaching mode of undergraduate colleges and universities, and finally puts forward improved methods and suggestions, such as improving practical teaching scheme model and strengthening college-enterprise double cultivation mode so as to provide direction for practical education in undergraduate colleges and universities and to convey more useful applied talents for society.
\end{abstract}

\section{Keywords}

Practical Education Mode • Applied • Improved Method • Talents

\footnotetext{
* General topic of pedagogy in 2014 under the 12th Five-Year Plan of the National Social Science Foundation. Project NO. BIAI40106

${ }^{1}$ Correspondence to: Min Wang (PhD), Institute of Geography and Tourism, Qilu Normal University, Jinan 250200, China. Email: qvfuwangmin@163.com
} 
The core idea of practical education in local applied undergraduate colleges and universities is humanistic education which complements with pragmatic education. The two promote and complement with each other with the mainstream orientation of training more practical talents for the society as a guide and policy of education (Chen, Li \& Wang, 2014). Compared with the corresponding undergraduate degree education in the local colleges and universities, applied cultivation teaching focuses on students' ability to solve problems, and to analyze and summarize the practical problems by using the theoretical knowledge and methods independently. Applied cultivation teaching aims at cultivating talents who have the thought of thinking problems and solving difficult problems, and have job skills and qualifications required in specific posts in the society so as to adapt to the training mode of various posts in the society.

The applied talent teaching mode emphasizes practical education, breaks free from the inherent theory teaching, and improves the cultivation of college talents in a fresh and active way so that students can arouse their enthusiasm, think and practice subjectively. In addition, students can flexibly combine theoretical knowledge with practical methods of operation and complete the practical problems in an optimal way to achieve the result of applying what they have learnt (Shirsavar, 2004).

Since the beginning of the new century, colleges and universities in China have expanded enrolment plan for many years in response to the call of the state to expand enrollment and train more talents so that the number of graduates increases greatly every year, making the problem of "graduation means unemployment" faced by graduates more serious (Rickles et al., 2012). According to the actual survey data, the market for providing jobs in the society is lower than that of graduates, and it is an absolute difference in quantity. From the fundamental point of view, most of the students in colleges and universities stay in the reserve period of theoretical knowledge, which is the problem of the difference between the needs of enterprises and the self-ability of college graduates. The main reason for this difference lies in that the local higher education institutions don't take the actual needs of the society as the starting point to train more practical talents for the society.

The cultivation of college students in local colleges and universities mostly stays in the transmission of book knowledge. After over a decade of study, college students finally enter colleges and universities to study. However, what waits for them is still a large number of theoretical knowledges, so that students' practical practice ability isn't fully improved, which basically can't meet the needs of various social posts. Some colleges and universities even carry out rapid "remodeling" for graduates upon graduation, hoping to enhance students' practical hands-on skills in a short period of time to make up for the defects over the course of four years (Xiumiao \& Jun, 2011). Therefore, the new undergraduate colleges and universities in the enrolment plan and training education, take applied talents as the primary goal of training so that students can smoothly integrate into the society after graduation, and can better adapt to the market and service society. In this way, we can directly solve the problem of "have grandiose aims but puny abilities" of students so as to improve the employment rate of students and help college graduates to establish correct career values.

In the teaching process of undergraduate education, practical educational mode should be put in an important position, and should be interpenetrated with theoretical teaching mode to form the educational idea that takes improving students' scientific research thinking, practical operation ability, key problem handling ability, 
ability to combine theory with practice and professional accomplishment ability as the core in undergraduate educational so that the undergraduate college graduates can have a higher professional quality and certain innovative practice ability. Therefore, the cultivation of applied talents should be taken as an important basis for the evaluation of comprehensive indicators in colleges and universities. The cultivation mode of practical education shall be taken as the core goal, hoping that applied talents can play a greater role in the society. Thus, it is very important to establish a perfect practical educational mode in local applied colleges and universities (Hubball \& Burt, 2011).

\section{Main Problems and Reasons in the Practical Teaching Mode of Undergraduate Colleges and Universities}

\section{Main problems}

In the education training mode of most local undergraduate colleges and universities, practical education means isn't taken as the core teaching content, and the content and method of practice is too single, lacking innovation and comprehensiveness so that students aren't able to interact on an effective platform. Thus, the main problems in the practical teaching mode of undergraduate colleges and universities are summarized as shown in Figure 1.

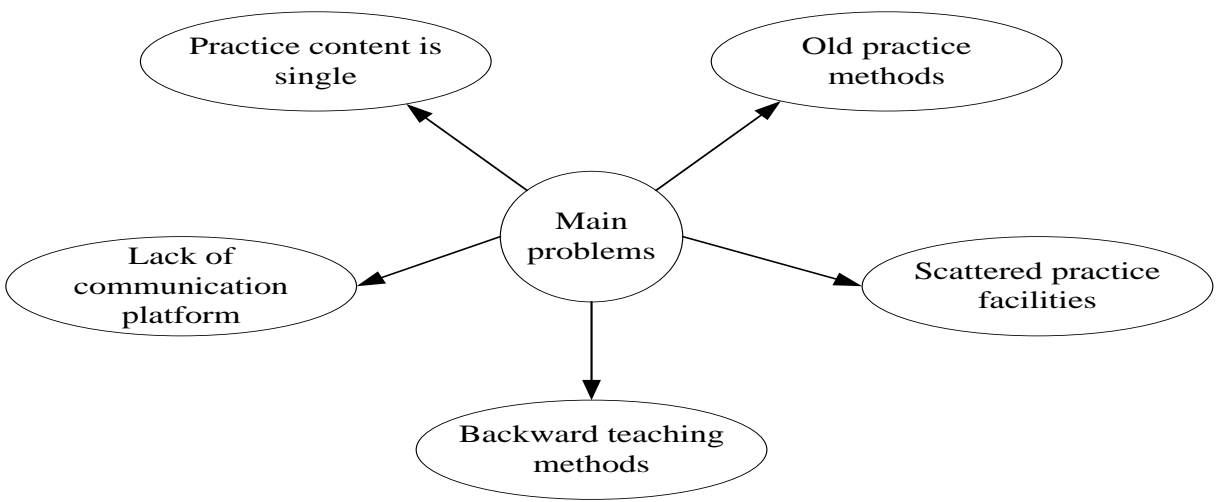

Figure 1. Main problems of practical teaching mode in undergraduate colleges and universities.

The first is backward teaching methods. Local colleges and universities still train students according to the traditional "infusing" teaching method and "flow" process, leading to that it is difficult for graduates to change from knowledge-based talents to ability-based talents. The so-called "flow" process mainly refers to guiding students through practical teaching methods such as social practice, teaching visits and case analysis. Students are still unable to fully exert their subjective initiative and still passively accept knowledge for a long time. Their self-innovation and operation abilities haven't been properly trained and improved, so it is difficult to apply the "infused" knowledge to practical work flexibly (Skrabal, Turner, Jones, Tilleman \& Coover, 2012). 
Wang / Study on Practical Education Mode of Local Applied Undergraduate Colleges and Universities.

The second is scattered practice facilities. Some of the teaching practice facilities used between teaching and research departments and laboratories in colleges and universities can't be fully utilized, which is a kind of waste of resources. Various hardware facilities can't be fully used to form a system and are in a state of "single fight". The lack of a unified management mechanism doesn't maximize the use of all practical teaching facilities or fully play the role of practice.

The third is lack of communication platform for students. In the current undergraduate education, various kinds of associations attract a large number of students to participate in, and these associations can well cultivate and enhance students' interests and practical ability. It is an important way for students to improve their selfability during their undergraduate study. However, most of student associations are commonweal, literary, artistic, and competitive, and there are few student associations with strong specialty so that they can't provide a good professional communication platform for students (Leung et al., 2016).

The fourth is single practice content. In the teaching plan of undergraduate colleges and universities, except for the necessary courses occupying a large amount of time, the time and resources of practice teaching are compressed to a small share so that the practice content is often only a single direction of operation, and knowledge isn't well digested (Jin \& Bridges, 2014). In addition, practice experiments and contents are independent of each other, and the correlation between them isn't very close so that it is difficult to connect the learn knowledge in one line from beginning to end, that is, when the undergraduate students graduate, it is also very difficult for them to participate in the complete practice of a project completely. They can't see the key points and importance of knowledge from the overall situation, making it difficult to use the learned content comprehensively.

The fifth is backward education methods. Enterprises in society will have new products in every year's operation. Along with the progress of society, new reforms and innovations will take place. However, the education methods in colleges and universities are still the same as they were ten years ago or even twenty years ago. The lack of connection with the operation way and management methods of enterprise makes it difficult for graduates from undergraduate colleges and universities to adapt to the mode of high-intensity work and fastpaced operation.

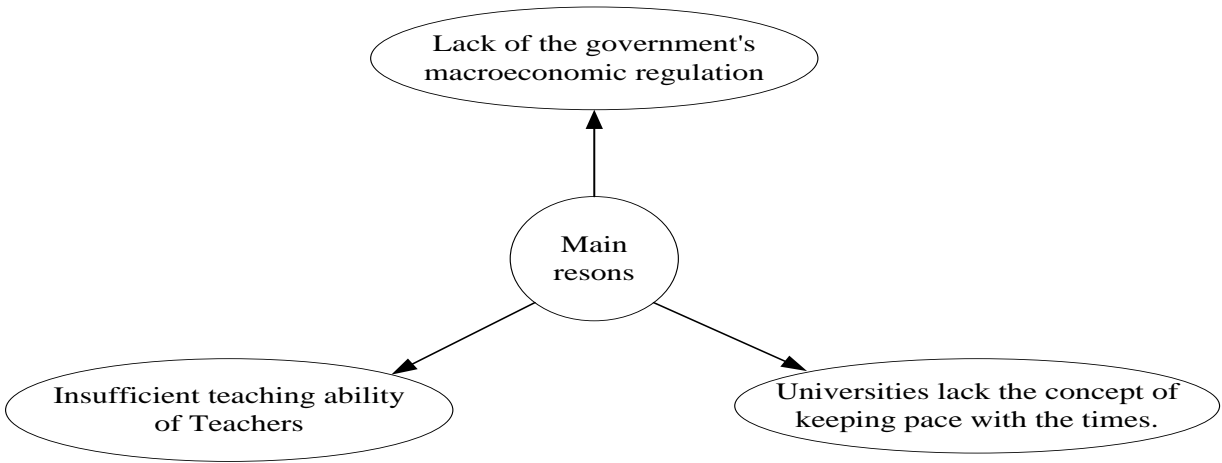

Figure 2. Main reasons of practical teaching mode in undergraduate colleges and universities. 


\section{Main reasons}

Based on the main problems mentioned above, three main reasons are lack of government's macroeconomic regulation, lack of concept of keeping pace with the times in colleges and universities and insufficient teaching ability of teachers, as shown in Figure 2.

First, local government's macroeconomic regulation is not enough. Government and Party and government offices at all levels are involved in higher education too much. There are many educators of "layman" management major. Managers have greater and higher authority, and the main leaders of colleges and universities will also follow the trend. The idea and management method of running a school will also take the guidance of the superior as the main direction, but don't combine the actual needs of the society or keep pace with the times. We should adjust and optimize the arrangement of courses and practice courses in time according to the actual needs of the society. Therefore, the strength of government's macroeconomic regulation is worth discussing.

Second, the idea of keeping pace with the times in many local applied colleges and universities isn't strong. Applied colleges and universities don't give full play to their own advantages on the standpoint, but imitate " 985 " and "211" famous universities. They don't know that the standpoints of the famous universities and applied colleges and universities are obviously different. The former is to train theoretical research and comprehensive talents while the latter is to train hands-on practical ability and highly operational talents. Blind imitation doesn't keep pace with the times or fully understand the true meaning of education, which will only make their advantages become weaker and weaker and gradually eliminated by the society.

Third, the teacher's teaching ability is insufficient. In most colleges and universities in China, it is easier to produce results from the direction of scientific research while practical work is not recognized by most people. Therefore, doctoral students are everywhere in the team of teachers in colleges and universities, and doctors from various famous universities and returnees are welcomed by colleges and universities. However, these doctors don't have a very strong ability to operate and practice, and few have participated in specific production and construction, resulting in that teaching scheme and design aren't fully integrated into the modern social application, let alone the use of innovative production methods to increase productivity (Monaghan et al., 2011).

\section{Improved methods and Suggestions}

\section{Improving practical teaching scheme model}

In the practice of practical courses, local applied colleges and universities should strictly set up three main modules, such as classroom practice simulation, extracurricular practice operation and simulation practice training.

Encourage students to start their own businesses in the design of classroom practice teaching In modern society, it has become a trend for college students to start their own business independently, which can not only relieve the employment pressure, but also enable students and schools to locate their own foothold 
more precisely and accurately in the continuous exploration. In particular, the cultivation of applied talents should take the "project guidance" in the classroom practice as the starting point and maximize the utilization of software and hardware resources in colleges and universities. Multi-orientation, multi-perspective and multiaspect integration ways should be used to encourage students to discover their own potentials in curriculum practice. We should apply for innovation project topics and international competitions from the course design, and derive more subsidiary industry projects from the initial "project guidance" through a series of experience and accumulation. In the platform of entrepreneurship development, we can give full play to the abilities of the applied students, enhance the team cooperation consciousness and solve the "knotty problems" and produce the classroom practice model of subsidiary project industry from the "project guidance", as shown in Figure 3.

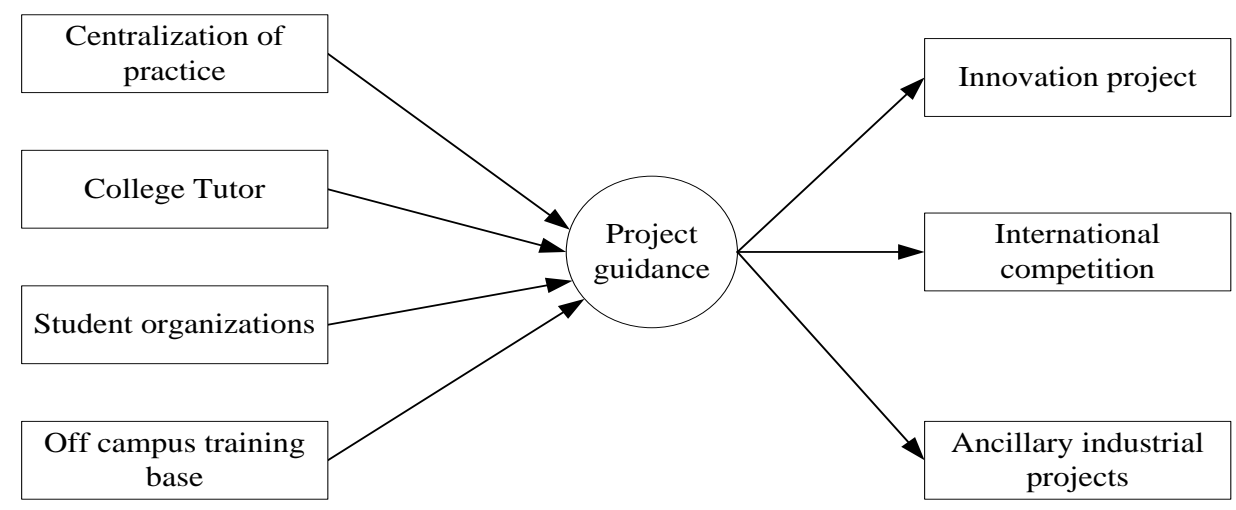

Figure 3. Mode of classroom practice.

Put more extracurricular practice into student associations: The student associations play an important role in colleges and universities in modern society. The environment is relatively fair and transparent for students. Besides, there is a certain degree of organizational construction and regular constraints to the point. Therefore, more extracurricular internship tasks are set up in different grades and majors with student associations as basic units, and concrete practical operations are carried out. The traditional pseudo-practice mode based on practical teaching design is innovated into the practice mode of mutual-urging learning. The model of the student associations' running the extracurricular practice operation is shown in Figure 4.

Accomplish the conversion of students' knowledge and ability in simulation practice In the study of theoretical knowledge and the development of practical activities, the conversion of knowledge and ability is weak in local applied colleges and universities so that the learnt theoretical knowledge can't be fully applied in the concrete problem solving process. In the concrete simulation practical training, we can use the idea of "learning while doing" and "happy-type" teaching mode, which can not only improve students' interest in practical learning, but complete the transition of theoretical knowledge and teaching practice in a short time, improving the teaching quality to the maximum extent. The concrete simulation training model is shown in Figure 5. 


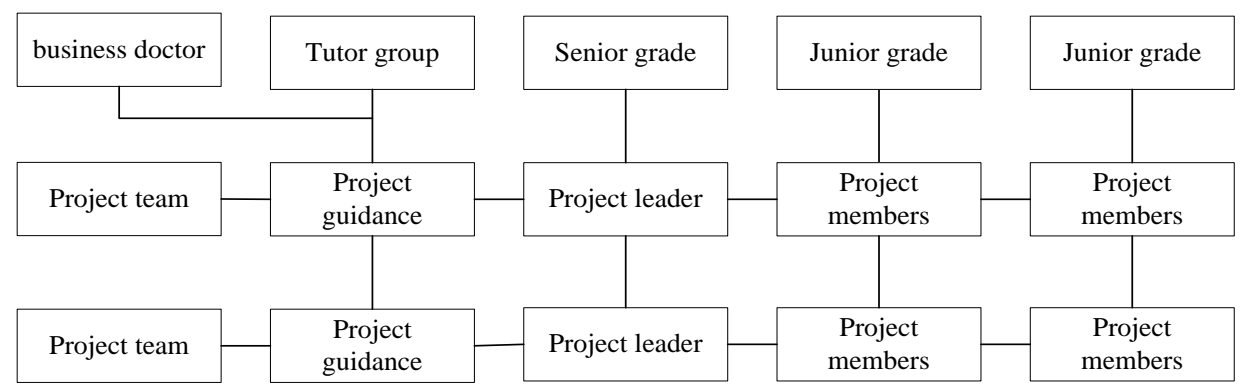

Figure 4. Mode chart of extracurricular practice with student associations as units.

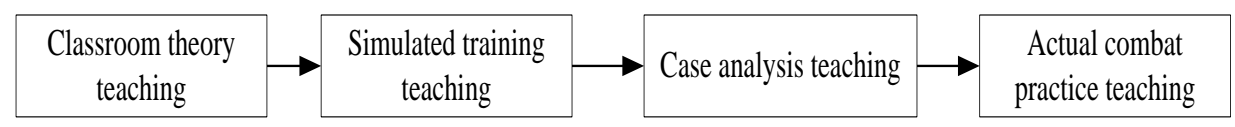

Figure 5. Mode chart of simulation training.

\section{Strengthening college-enterprise double cultivation mode}

Local colleges and universities should keep close contact with well-known enterprises in the society in a timely manner, and understand the latest social trends and needs through communication of senior engineers and experienced technicians with teachers and students. Under the guidance of enterprises, local colleges and universities should arrange teachers and students to visit and study in the enterprise base to produce a positive stimulating effect on the students from the sense point of view, allowing the cultural environment and workflow of the enterprise to be fully rooted in the student's professional learning (Souza et al., 2016).

If the conditions allow, we should sign the training agreement with the local enterprises and send students to the enterprise for practice at regular and quantitative intervals so that the practice of the enterprise gradually becomes the most important training mode outside the campus. The cultivation of colleges and universities and enterprises should be combined as much possible, which not only trains students' practical hands-on ability, but also increases students' experience and make them define the direction of future work (Tarhini, Hone \& Liu, 2015). At the same time, it also promotes the publicity and public welfare of the local characteristic enterprises so as to cultivate more meaningful applied talents for the society. The concrete college-enterprise double cultivation mode is shown in Figure 6.

\section{Conclusion}

Along with the rapid development of national economy and the urgent demand of applied talents, the demand for applied undergraduate talents in the society will continue to grow. Although the traditional applied 
Wang / Study on Practical Education Mode of Local Applied Undergraduate Colleges and Universities.

local colleges and universities have made certain achievements in the cultivation of talents, they can't keep pace with the social development. Therefore, based on the importance of the applied teaching mode, this study analyzes the main problems and reasons in the practical teaching mode of undergraduate colleges and universities, and finally puts forward improved methods and suggestion, such as improving practical teaching scheme model and strengthening college-enterprise double cultivation mode, hoping to provide direction for practical education in undergraduate colleges and universities so that that graduate applied talents can better keep a foothold in the modern society.

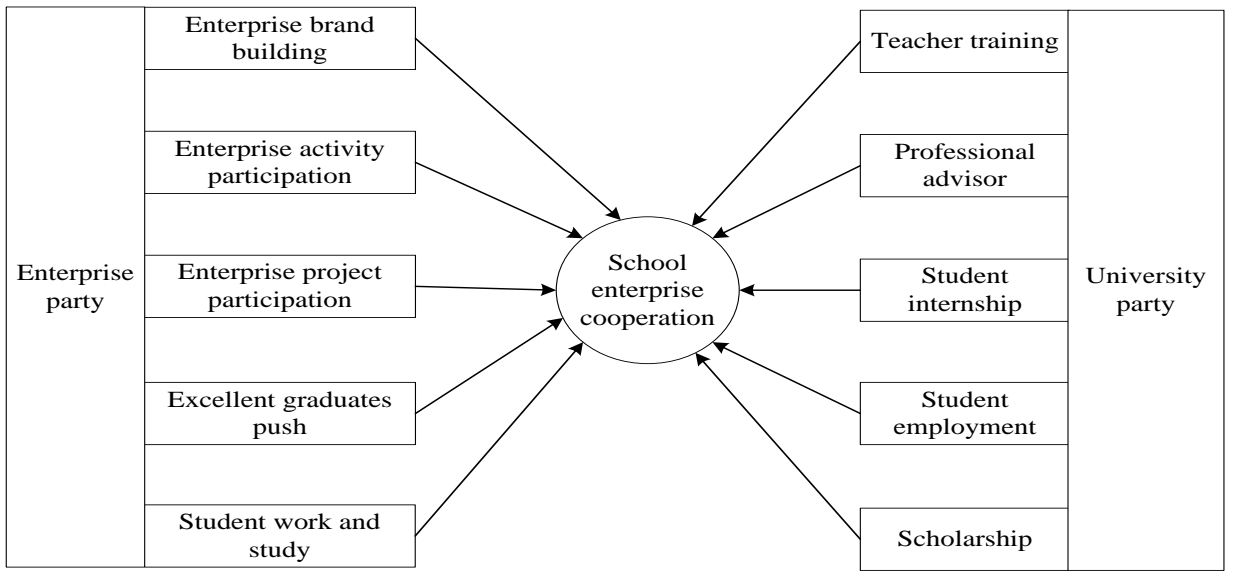

Figure 6. Dual training mode of universities and enterprises.

\section{References}

Chen, D., Li, Z., \& Wang, T. (2014). Exploration and practice: A competition-based project practice teaching mode. Mechatronics, 24(2), 128-138. https://dx.doi.org/10.1016/j. mechatronics.2013.12.009

Hubball, H., \& Burt, H. (2011). Learning outcomes and program-level evaluation in a four-year undergraduate pharmacy curriculum. American Journal of Pharmaceutical Education, 71(5), 90. http://dx.doi.org/10.5688/aj710590

Jin, J., \& Bridges, S. M. (2014). Educational technologies in problem-based learning in health sciences education: A systematic review. Journal of Medical Internet Research, 16(12), e251. http://dx.doi.org/10.2196/jmir.3240

Leung, A. A., Nerenberg, K., Daskalopoulou, S. S., Mcbrien, K., Zarnke, K. B., \& Dasgupta, K., et al. (2016). Hypertension canada's 2016 canadian hypertension education program guidelines for blood pressure measurement, diagnosis, assessment of risk, prevention, and treatment of hypertension. Canadian Journal of Cardiology, 32(5), 589-597. http://dx.doi.org/10.1016/j.cjca.2016.02.075 
Wang / Study on Practical Education Mode of Local Applied Undergraduate Colleges and Universities.

Monaghan, M. S., Cain, J. J., Malone, P. M., Chapman, T. A., Walters, R. W., \& Thompson, D. C., et al. (2011). Educational technology use among us colleges and schools of pharmacy. American Journal of Pharmaceutical Education, 75(5), 87. http://dx.doi.org/10.5688/ajpe75587

Rickles, N. M., Maclean, L. G., Hess, K., Farmer, K. C., Yurkon, A. M., \& Ha, C. C., et al. (2012). Teaching medication adherence in us colleges and schools of pharmacy. American Journal of Pharmaceutical Education, 76(5), 79. https://dx.doi.org/10.5688/ajpe76579

Shirsavar, S. A. (2004). Teaching practical design of switch-mode power supplies. IEEE Transactions on Education, 47(4), 467-473. https://dx.doi.org/10.1109/te.2004.825066

Skrabal, M. Z., Turner, P. D., Jones, R. M., Tilleman, J. A., \& Coover, K. L. (2012). Portfolio use and practices in us colleges and schools of pharmacy. American Journal of Pharmaceutical Education, 76(3), 46. http://dx.doi.org/10.5688/ajpe76346

Souza, A. C., Moreira, T. M., Oliveira, E. S., Menezes, A. V., Loureiro, A. M., \& Silva, C. B., et al. (2016). Effectiveness of educational technology in promoting quality of life and treatment adherence in hypertensive people. Plos One, 11(11), e0165311. http://dx.doi.org/10.1371/journal.pone.0165311

Tarhini, A., Hone, K. S., \& Liu, X. (2015). A cross-cultural examination of the impact of social, organisational and individual factors on educational technology acceptance between British and Lebanese university students. British Journal of Educational Technology, 46(4), 739-755. http://dx.doi.org/10.1111/bjet.12169

Xiumiao, Z., \& Jun, Y. (2011). Reflection and exploration of interactive teaching in college English intensive reading classroom of newly built universities under network environment in minority areas. IEEE, 513-517. http://dx.doi.org/10.1109/ICFCSE.2011.131 